\title{
Medzi historickým faktom a fikciou: interdiskurzívne konštruovanie fikčných svetov $v$ súčasnej slovenskej próze s historickou tematikou
}

\section{IVAN JANČOVIČ}

DOI: https://doi.org/10.31577/WLS.2021.13.4.1

Próza s historickou tematikou je oproti iným fikčným umeleckým textom prepojená s mimoliterárnou skutočnostou osobitným spôsobom. Prejavuje sa to v produkčnej aj recepčnej oblasti literárnej komunikácie. „Historickost" témy znamená, že niektoré jej súčasti - udalosti, osoby, časové, priestorové zložky a pod. - majú svoj korelát $\mathrm{v}$ reálnom minulom dianí, presnejšie vyjadrené, $\mathrm{v}$ stopách po minulom dianí a v spôsobe, akým sú spoločensky interpretované. Autor zložky témy zámerne znakovo konštituuje tak, aby čitatel rozpoznal súvztažnost̉ medzi fikčnou entitou a jej náprotivkom z reálnej minulosti. Súčastou vytvárania aj čítania historickej prózy je „autorsko-čitatel'ská konvencia historického žánru ako fiktívnej tematizácie odvinutej od historického faktu. Jednoducho, historický fakt (osoba, udalost', objekt, listina) tvorí pre text historického žánru východisko. [...] historický žáner ako epické (literárne, estetické) zobrazenie je druhotnou imagináciou“ (Bílik 2008, 41). Uvedená konvencia môže fungovat vtedy, ked' majú obe strany osvojené poznanie v rámci jednej „kultúrnej encyklopédie“.

\section{INTERDISKURZÍVNOSŤ HISTORICKEJ PRÓZY}

Predstava o minulosti sa v istom (napríklad národnom) spoločenstve vytvára prostredníctvom viacerých diskurzov (vzdelávací systém, médiá, politika, umenie, individuálna skúsenost̉ uchovávaná rodinnou pamätou...) a je súčastou sociálnej konštrukcie skutočnosti. Podstatným spôsobom ju ovplyvňuje špeciálny vedecký diskurz: poznávanie minulosti je doménou historických vied, ktoré ustalujú spoločnostou akceptovaný obraz minulého diania. Tento vedecký diskurz produkuje a komunikuje poznanie, ktoré spoločnost' akceptuje ako legitímne výpovede o našom svete, pretože ide/má íst' o teoreticky a metodologicky fundované poznanie vystavené procedúram akceptácie vnútri príslušnej epistemickej komunity. Predstavuje relatívne stabilnú konštrukciu zabezpečujúcu pre spoločnost' koherenciu jej predstáv o skutočnosti. Aplikujúc slová Emila Višňovského $(2019,62)$, pri poznávaní minulosti nemáme vyššiu inštanciu, na ktorú by sme sa ako racionálne a reflexívne bytosti obracali, než je historická veda. Pre analýzu historického žánra umeleckej prózy môže byt súvislost’ so špeciálnou vedou zaujímavá. Zjednodušene sa dá povedat, že odtial', z (re)kon-

* Príspevok vznikol v rámci projektu VEGA 2/0111/20 „Interdiskurzívne konštruovanie reality v literatúre“. 
štrukcie minulého vytvorenej historickým diskurzom, berie autor historickej prózy niektoré súčasti témy a historický diskurz je tiež zdrojom čitatelových vedomostí, vdaka ktorým dokáže tieto tematické zložky rozpoznat ako reprezentácie toho, čo sa kedysi stalo.

Väzba medzi historickým a fikčným diskurzom je do istej miery relativizovaná tým, že povedomie o minulosti si spoločnost’ vytvára prostredníctvom interdiskurzívnej siete (napríklad v systémoch vzdelávania, politiky, masmediálnej komunikácie), v ktorej historická veda predstavuje len jeden, $\mathrm{z}$ hladiska dosiahnutého poznania najkompetentnejší, no nie vždy najvplyvnejší diskurz. Časti poznania minulosti koncentrovaného v historických vedách sú natolko vrastené do „bežného“ povedomia o skutočnosti, že $\mathrm{v}$ recepcii ich literárneho spracovania sa pozadie špeciálneho diskurzu výraznejšie nevníma; napríklad o gulagoch v bývalom Sovietskom zväze „niečo" vieme bez toho, aby sme študovali práce historikov, zdroje našich poznatkov majú skôr sprostredkujúci charakter. Osobitnú problematiku predstavuje prepojenie medzi výkladom minulosti a ideológiou, utváranie obrazu minulosti ako zložky kultúrnej pamäti $\mathrm{v}$ súlade $\mathrm{s}$ kreovaním národnej identity, národnej (seba)prezentácie a pod., pričom práve historická próza zohrávala v národných literatúrach podstatnú úlohu. Naznačené súvislosti však nič nemenia na tom, že vztah medzi historickým a fikčným diskurzom je pre historickú prózu dôležitý. Historický žáner sa dá opísat ako interdiskurzívne konštruovaný invariant autorsko-čitatelských konvencií; jeho produkčno-recepčné varianty aktivujú interdiskurzívne založené konanie, bez ktorého by žánrová konvencia náležite nefungovala.

Ako čitatel' identifikuje v historickom žánri tie zložky témy, ktoré patria rovnako do historického aj do fikčného diskurzu? Pomerne zretelné sú takéto tematické prvky v podobe stopy, teda niečoho, čo ostalo po inak neprístupnom minulom dianí a čo je pre historikov základom rekonštrukcie minulosti. Dokumenty, fotografie, fakty zistené $\mathrm{v}$ archívoch, poznatky archeológov atd. - pre historika stopy minulosti - môže autor historickej prózy začlenit do témy textu, pričom so sebou prinášajú viac či menej ustálenú historickú interpretáciu, zastupujú viac či menej komplexný historický naratív o minulom dianí. Na tomto pozadí, „garantovanom“ špeciálnym diskurzom histórie, čitatel' stopy identifikuje a rozumie im. Lenže v sociokultúrnej praktike nazývanej umelecká literatúra stopa historického diania neostáva tým istým, čím bola v historiografickom diskurze. Presnejšie vyjadrené, ostáva aj tým, ale zároveň sa môže stat niečím iným - v závislosti od autorskej intencie tematickej realizácie. V historickom žánri nadobúda stopa podvojný charakter. Nejde o žiadnu novinku. Ked’ Tomáš Kubíček sledoval ponímanie stopy v koncepcii Paula Ricœura, zdôraznil, ako dôsledne ju francúzsky filozof spája s historickým diskurzom: „Stopa je [...] znamením př́islušnosti narativu k vyprávění historika a nikoliv k vyprávění romanopisce. Má totiž schopnost verifikační - a to jako součást kauzálního řetězce, který historik buduje. Stopa přechodem do fikčního žánru ztrácí svůj charakter stopy - datované události, spojení se světem, s jeho časovostí, prríčinností a logikou“ $(2010,87)$.

Hoci téma historického žánru aktivuje poznatky o skutočnom minulom dianí, je spracovaná $\mathrm{v}$ znakovom médiu, ktorého funkciou nie je objektívne či pravdivé referovanie o tom, čo sa stalo, ale vytvorenie „druhotnej imaginácie“. Osobitost' historické- 
ho žánru spočíva $\mathrm{v}$ možnosti recipovat textovo vytvorené objekty jednak v súradniciach fikčného textu, jednak vzhladom na ich reflexiu v rámci historického poznania. Dvojakú príslušnost' niektorých zložiek fikčného sveta historickej prózy vyjadruje pojem salientné štruktúry, $\mathrm{v}$ ktorých „náleží objekty ke dvěma rozdílným skupinám světů a mají v každé z těchto skupin rozdílné vlastnosti, funkce a ontologickou váhu“ (Pavel 2012, 65). Takúto štruktúru tvorí aktuálny svet v spojení s akýmkolvek svetom fikčným; vzhladom na (jazykovú) sprostredkovanost̉ aktuálneho sveta možno o podobnom type štruktúry uvažovat pri spojení dvoch odlišných svetov vytváraných textom historickým a fikčným. Pre oba svety platí, že sú možnými svetmi, sú prístupné z aktuálneho sveta, historický aj fikčný konštrukt je založený naratívnou štruktúrou, no zároveň platí, že svety historické podliehajú obmedzeniam, ktoré sa nevztahujú na svety fikčné (podrobnejšie Doležel 2002, 341).

Text historického žánru teda obsahuje dva druhy objektov, zodpovedajúce členeniu na objekty domáce („zrodené“ v príbehu) a objekty pristahované (imigrované do príbehu). Historický žáner v personálnom pláne i v časopriestore fikčného sveta absorbuje vybrané historické fakty a objekty, teda entity, ktoré možno vztahovat' $k$ aktuálnemu svetu, presnejšie $\mathrm{k}$ jeho neliterárnym reprezentáciám. O týchto súčastiach platí, že nie sú vytvorené výlučne textom, ale majú svoje koreláty mimo fikčného sveta. Odtial môže vychádzat” „tradovaná predstava, že texty historického žánru si vyžadujú iné pravdivostné hodnotenie ako texty žánrov ostatných“ (Bílik 2008, 13). Pokial má byt uvažovanie o historickom žánri konzekventné, je potrebné rešpektovat', že objekty exportované z nefikčných znakových reprezentácií aktuálneho sveta (napr. historický text alebo širšie ponímané historické poznanie) do fikčného sveta prechádzajú ontologickou premenou. Preto i tie súčasti, ktoré majú svoj náprotivok $\mathrm{v}$ „realite“, sú predovšetkým prvkami fikčného textu a jeho pravdivost je posudzovaná inými kritériami ako v prípade nefikčných naratívov. $\mathrm{V}$ tejto súvislosti píše Dorrit Cohn o „dvojposchodovom“ referenčnom modeli: konštatuje, že „reálne“ súčasti literárneho textu sa kontaminujú s vymyslenými, dochádza $\mathrm{k}$ ich imaginatívnej manipulácii, čím „vnější reference přestávají být po vstupu do fikčního světa vskutku vnější. Jsou totiž [„reálne" súčasti literárneho textu - pozn. I. J.] takříkajíc infikovány zevnitř, podrobeny tomu, co Käte Hamburgerová označuje jako ,proces fikcionalizace“ (Cohnová 2009, 29).

Historický žáner však do istej miery problematizuje teoreticky priezračné odlíšenie fikčného sveta od iných svetov, pretože do obligátnych charakteristík fikčného sveta ostáva vklinená väzba na východiskové historické fakty: na jednej strane platí, že historická próza nereferuje $\mathrm{k}$ nejakej ontologicky nezávislej a časovo predchádzajúcej dátovej základni spôsobom prislúchajúcim nefikčnému naratívu, ${ }^{1}$ na druhej strane sledovanie viac či menej presných korešpondencií s mimotextovými faktmi je súčastou produkčnej aj recepčnej aktivity. Začleňovanie historických stôp medzi tematické zložky historickej prózy sa uskutočňuje mnohorakými spôsobmi pohybujúcimi sa od pólu „citovania“ samotnej stopy (korešpondencia, iné autentické písomnosti, fotografie) po pól mystifikácie na úrovni stopy (vydávanie autorom vytvorených "stôp“ za reálne jestvujúce, spájanie zachovaných fotografií s historicky nepravdivými popismi atd'.), pričom organizujúcim činitelom týchto variácií je autorská intencia pri 
literárnom spracovaní témy. ${ }^{2}$ Podvojná príslušnost niektorých tematických prvkov, ich prepojitelnost' s mimotextovou stopou a zároveň ich príslušnost' k svojbytnému fikčnému svetu je dôležitou súčastou (literárnych, užšie žánrových) „pravidiel hry“. Umožňuje historickým prózam navodzovat oproti iným postupom vytvárania fikcie špecifické recepčné stimuly. ${ }^{3}$

\section{HISTORICKÝ FAKT A FIKCIA: PRÍKLADY ZO SÚČASNÝCH SLOVENSKÝCH HISTORICKÝCH ROMÁNOV}

Prechod mimotextovej skutočnosti do témy historickej prózy ako transformačný proces sui generis nezriedka signalizujú autori priamo $\mathrm{v}$ texte, presnejšie $\mathrm{v}$ jeho rámcových zložkách. Aj tvorcovia súčasných slovenských historických románov v tomto zmysle využívajú grafický (fotografie, rodostrom, mapa, výtvarné riešenie, grafika obálky a predsádky) a textový rámec kníh (titul, podtitul, dedikácia, motto, podakovanie, predhovor, doslov, poznámky, dodatky). Platí to $\mathrm{v}$ rôznej miere o knihách Pavla Rankova Matky (2011), Jara Riháka Pentcho (2015), Jozefa Banáša Zastavte Dubčeka! (2009), Silvestra Lavríka Nedelné šachy s Tisom (2016) a Posledná barónka (2019). Grafický a textový rámec sa v nich stáva „místem vypjaté sémantické hry na skutečnost a na literaturu" (Hodrová 2001, 223). ${ }^{4}$ Zaujatie postoja k textu a k mimotextovej skutočnosti je zretelné hned’v prvých rámcových zložkách, v titule a prípadnom podtitule.

Jednoznačnú väzbu so skutočnostou signalizuje titul Banášovej knihy Zastavte Dubčeka!, rovnako priama, hoci v širšom povedomí málo známa, je väzba v titule Pentcho (skutočné meno reálneho parníka, na ktorom skupina židovských pasažierov odchádzala v roku $1940 \mathrm{~s}$ vidinou vlastného štátu $\mathrm{z}$ Bratislavy nedlho pred nadchádzajúcou katastrofou). Knihy obsahujú podtituly, ktoré kopírujú intenciu titulov, spresňujú ich, zdôrazňujúc príbehovost podania témy, v druhom prípade aj žánrové východisko. ${ }^{5}$ Obe knihy obsahujú fotografie presne identifikovaných reálnych ludí, ktorí boli aktérmi udalostí transponovaných do textu. V spôsobe tejto znakovej reprezentácie sú však medzi postupmi autorov podstatné rozdiely, naznačené hned’ v rámcových zložkách.

Publikácia Jozefa Banáša Zastavte Dubčeka! je v paratextových, textových aj obrazových častiach vybavená jasnými signálmi, že vypovedá o reálnom historickom dianí spôsobom podliehajúcim overovaniu pravdivosti uvádzaných faktov, ale aj ich naratívnej interpretácie. Počnúc obálkou cez fotografie vnútri knihy vizualizuje osobnost̊ Alexandra Dubčeka ako jednoznačný denotát knihy-veci, knihy-materiálneho objektu aj knihy-„,diela“, jej čitatel’skej konkretizácie. Posudzovatelia uvedení v rámcovej zložke na začiatku knihy, rovnako zoznam použitej literatúry na jej konci odkazujú $\mathrm{k}$ atribútom odborného textu, ktorý sprostredkúva objektivizované poznanie založené na vedeckých postupoch. Tento zámer podčiarkuje venovanie („Venujem tým, ktorí hladajú pravdu.“) a konštatovanie v úvode, že kniha má hlavne mladým lud'om pripomenút Dubčekovu osobnost', jeho účinkovanie a význam v moderných národných dejinách. Preukazovanie „pravdivosti“, hodnovernosti, overitelnosti vytvoreného naratívu zodpovedá významu osobnosti Alexandra Dubčeka v našich moderných dejinách, jeho prevažne pozitívnemu obrazu vo verejných 
diskurzoch. Ukotvenie historickej osobnosti v širokom spoločenskom povedomí predstavuje výrazné pozadie, na ktorom je vnímaná akákolvek jej literárne produkovaná perspektivizácia. $\mathrm{V}$ tomto prípade autor volí perspektivizáciu afirmatívnu k oficiálne ustálenej pozitívnej historicko-hodnotovej interpretácii Dubčekovho pôsobenia a naplno využíva historické stopy a doterajšie historické výklady v ich mimoliterárnej platnosti - vo svete jeho textu neprekonávajú vlastne žiadnu viditelnú premenu, naopak, práve ich podčiarkovaná „reálna“ platnosṫ má byt najspolahlivejším garantom autorovho zámeru. Pri konštrukcii naratívu nie je $\mathrm{v}$ pásme aktantov diania využitá žiadna $\mathrm{z}$ možností fikčnej literatúry, osoby sú uvádzané pod svojimi skutočnými menami, politickí aktéri sú zachytávaní priamo pri najdôležitejších udalostiach historického významu. Stopy a ich naratívne spracovanie majú žit vo svete „románu“ nad’alej životom historickej stopy, pričom si Banáš nárokuje pozíciu odborne fundovaného a spolahlivého autora.

Prečo má byt potom kniha Zastavte Dubčeka! „románom“ (tak ju označuje Banáš na vlastnej internetovej stránke, takto figuruje v ponukách kníhkupectiev aj v mnohých ohlasoch) a nie odbornou prácou alebo beletrizovanou biografiou? Motivácia potvrdit obsadenie spoločenskej roly spisovatela či marketingová výhoda románu oproti iným útvarom sú v hre pri druhej možnosti. Prvá sa vylučuje spôsobom spracovania Dubčekovho života a pôsobenia. „Románovost" majú vo výrazovom pláne textu zabezpečit beletristické črty - priama reč „postáv“, fiktívne dialógy či postupy spojené s autorským (vševediacim) rozprávačom. Krížia sa tak dva režimy: jeden založený na verifikovatelnom odkazovaní $\mathrm{k}$ reálnym udalostiam a ich reálnym aktérom, druhý umožňujúci fiktívnymi prehovormi, dialógmi alebo líčením vnútorného diania aktérov predviest̉ rozprávané prostriedkami vlastnými literatúre, ktorá však overovaniu pravdivosti jednotlivých zložiek výpovede nepodlieha. Vdaka nim čítanie nadobúda istú pútavosť v mode „akoby“, príznačnom pre fikčnú literatúru. Vo všeobecnosti takýto postup akiste môže fungovat, v Banášovej knihe je však podstatne závislý od zdrojov, medzi ktorými sú na prvom mieste pamäti Alexandra Dubčeka Nádej zomiera posledná (1993). ${ }^{6}$ Nasýtenost' textu historickými stopami ani ich významová a hodnotová interpretácia sa potom nejavia ako výsledok práce autora; sú prenesené $\mathrm{z}$ iného zdroja a doplnené širšími historicky kontextualizujúcimi poznatkami. Snaha navodit románové spracovanie témy sa prejavila na povrchu textu použitím niekolkých elementárnych postupov umeleckej prózy. Stopy historického diania ostali fikčne netransformované, prevzaté ako pripravený sumár spolu s hotovou perspektivizáciou.

Pri porovnaní s opísaným postupom vyniká podstatne odlišná autorská stratégia Jara Riháka v knihe Pentcho. Hned'v rámcovej poznámke ${ }^{7}$ autor oddelil historické skutočnosti, ich aktérov a zachované stopy (fotografie, spomienky organizátorov plavby) od literárneho spracovania dramatických udalostí z čias druhej svetovej vojny. Explicitne uviedol rozdiel medzi prácou historika a svojím umeleckým stvárnením témy, inak vyjadrené, nastavil jasné produkčno-recepčné pravidlá, v ktorých má svoje miesto aj fikčné dotvorenie východiskového materiálu. Rihák nemá ambíciu poskytnút verné podanie priebehu akcie, ale jej literárne účinné predvedenie. Čitatel preto vie, že číta o obdivuhodnom počine konkrétnych ludí, o skutočnej plavbe 
starého riečneho parníka smerom $\mathrm{k}$ Palestíne, no zároveň sa $\mathrm{v}$ súlade $\mathrm{s}$ ohlásenými pravidlami môže presunút do homogénneho fikčného sveta.

Ďalšia kniha spracúva historickú tému spôsobom, v ktorom je väzba na konkrétne osoby a udalosti nepodstatná. Ťažisko predstavuje fikčný príbeh odkazujúci na čas druhej svetovej vojny a bezprostredne po nej, ked' sa mnohí ludia zo Slovenska ocitli v sovietskych pracovných táboroch. Trojica citátov uvádzajúca román Pavla Rankova Matky signalizuje tri podstatné aspekty vo vztahu medzi súčasnostou a minulostou. Úryvok zo Solženicynovho Súostrovia Gulag 8 poukazuje na úskalia historického románu - predovšetkým na nezrušitelnú dištanciu medzi súčasným a minulým: to, čo bolo, už nikomu nie je priamo prístupné a snaha pochopit minulost je poznačená odstupom a posunom toho, kto sa obzerá dozadu. Citát z Kadareho knihy Spiritus ${ }^{9}$ poukazuje na limity ludskej psychiky vnímat aj vysoko problémové až drastické podnety so zodpovedajúcou intenzitou. Konkrétne dokumenty svedčiace o hrôzach v táboroch a väzeniach po počiatočnom silnom pôsobení strácajú svoju naliehavost', sú platnou evidenciou čohosi prežitého, no zároveň ukončeného, uzavretého a oddeleného od súčasnosti. A napokon pasáž z druhej knihy Machabejcov ${ }^{10}$ vytyčuje morálny horizont konania, ktoré namiesto záchrany života uprednostňuje jeho obetovanie. Takýto prístup je opodstatnený tým, čo transcenduje prítomnost', čo sa dvíha z minulosti smerom hore a do budúcnosti. Záväzná skúsenost' so stvoritel'ským dielom Boha na počiatku dáva zmysel dobrovolne podstúpit smrt', lebo práve tak sa otvára zaslúbená perspektíva. Minulost má v prítomnom priam absolútnu platnost'.

Román Matky sa dá čítat ako prozaická odpoved’ na tri vzájomne prepojené okruhy otázok. Prvý okruh súvisí s existenciou faktov, dokumentov, stôp svedčiacich o minulom dianí a s problémom ich včleňovania do nášho skúsenostného komplexu. Môžeme minulost spoznávat prostredníctvom samotných dobových dokladov o nej? V istom zmysle nič nie je presnejšie a výpovednejšie než stopy, ktoré minulé dianie po sebe zanechalo, no tie vo svojej „holej fakticite“ postupne zapadnú v prachu archívov aj v pamäti. Druhý okruh otázok sa potom týka spôsobov účinného začleňovania minulého do prítomnosti. Jednou z možností je urobit z dokladov minulosti tému pre historický žáner umeleckej literatúry, pravda, s vedomím tažkostí naznačených citátom zo Solženicynovej knihy. Tu sa otvára nesmierne široká škála možností transformácie látkového (historického) podkladu do fikčného textu, pričom je podstatný účinok umeleckého textu. Tretí okruh otázok napokon smeruje $k$ významu a funkciám, ktoré môže poznanie (a dodajme, že najmä precítenie) minulého diania nadobúdat $\mathrm{v}$ aktuálnej prítomnosti, priamo $\mathrm{v}$ našich postojoch, reakciách, rozhodnutiach. Prijatie smrti v mene záväzku k minulosti je hraničným prípadom, no ani menej dramatické situácie, pri ktorých nadobúda hlas minulého silu, nemusia byt lahkým rozhodovaním.

Otázky navodené Rankovovým románom siahajú za hranice umeleckej literatúry. Hodnotenie úrovne prozaickej „odpovede“ na ne je záležitostou prebiehajúcej literárnovednej reflexie, na tomto mieste je dôležitejšia podstata otázok: dotýkajú sa samotného problému poznania minulosti, sprostredkúvania tohto poznania a jeho začleňovania do konštrukcie poznania sveta. $V$ knihe je súčastou témy problém prevedenia individuálnej historickej skúsenosti do epistemických mriežok spoločen- 
ských a humanitných vied. Ironizovaná snaha nie nevzdelaného, no školometského vysokoškolského pedagóga objektivizovat životnú drámu konkrétneho človeka nástrojmi vedeckých teórií je sprevádzaná jeho neschopnostou vnímat otriasajúce spomienky starej ženy - respondentky $\mathrm{v}$ rámci uplatnenia metódy oral history - v ich jedinečnosti a autentickosti. Naproti tomu do konania študentky-diplomantky sa rozprávaná skúsenost premieta $\mathrm{v}$ plnej životnej platnosti a ovplyvňuje jej privátne rozhodovanie.

Kým knihy Jozefa Banáša a Jara Riháka vychádzajú z reálneho konania jednoznačne identifikovaných osôb a kniha Pavla Rankova, naopak, podáva historickú tému rýdzo fikčným príbehom, abstrahujúc od konkrétnych personálnych aktérov, dva romány Silvestra Lavríka predstavujú postup, ktorý do fikčného textu zarad’uje množstvo historických stôp a využíva energiu ich „fikcionalizácie“, premeny na objekt iného (fikčného) sveta. Kniha Nedelné šachy s Tisom má podtitul Historický román inšpirovaný historickými udalostami a príbehmi ludí, ktorí ich museli žit (Lavrík 2016). V podakovaní autor uvádza, že príbehový pôdorys románu sa opiera o historickú faktografiu, ústne podanie a autorskú fikciu, pričom prvé dva zdroje „boli tomu tretiemu bezodným inšpiromatom“ (406). Nasleduje podakovanie historikom, pracovníkom archívov, knižníc, galérií, ktorí boli autorovi pri písaní nápomocní. Silná väzba románu s látkovou skutočnostou je podporená grafickými zložkami knihy: na predsádke sú historické mapy centra Bánoviec nad Bebravou do r. 1936 a 1945, vytvorené špeciálne pre túto príležitost', publikácia obsahuje množstvo dobových fotografií s popismi navodzujúcimi súvislost' s rozprávaným príbehom a jeho nositelmi. Rozprávačka má predobraz v konkrétnej Bánovčanke, takisto doloženej fotografiou. Príbeh je vedený tak, aby sa v diskurze dali použit rozsiahle citáty z novinových príspevkov či prejavov Jozefa Tisa, policajné rozkazy s presným uvedením zdroja a iné dobové dokumenty. Pre písanie o stále nejednoznačne vnímanej, kontroverznej etape našich národných dejín, ktorá spôsobila nesmierne tragédie, majú historické stopy - úryvky autentických Tisových textov, fotografie Bánoviec a ich obyvatelov, oficiálna fotodokumentácia vojnovej Slovenskej republiky, úradná korešpondencia - nenahraditelnú účinnost'. Ako reprezentácie ontologicky netextového sveta, $\mathrm{v}$ ktorom tiekla skutočná krv, umieralo sa, diali sa zločiny a popri tom ludia žili svoje obyčajné životy, hovoria rečou silnejšou než je akákolvek fikčná výpoved'. Môžu sa bez nej zaobíst'. No môžu v nej nadobudnút pozíciu, ktorá ich silu ešte umocní, pretože sa stanú zložkami textu navodzujúceho racionálno-emocionálnu spoluúčast príjemcu na vytváraní jedinečného fikčného sveta. Nedelné šachy $s$ Tisom sú dobrým príkladom toho, ako sa historická stopa prechodom do sveta literárneho textu fikcionalizuje, ako sa mení na jeho súčast', aby v literárnom diskurze plnila príslušné funkcie, no zároveň si aj vnútri fikčného sveta ponecháva niečo zo svojej predošlej existencie - akokolvek vnorená do vnútrotextového diania, nedovolí čitatelovi zabudnút, že bola a bude mimo textu a nezávisle od neho. Význam stopy mimo textu spočíva v jej svedeckej platnosti - jej prostredníctvom vieme o tom, že sa niečo nejako udialo. Sila stopy „premenenej“ na tematickú súčast prózy podstatne závisí od významového potenciálu textovej štruktúry, od interpretačnej podnetnosti a otvorenosti fikčného textu. Lavrík niektoré tematické zložky tohto druhu pone- 
cháva napohlad bez zmeny - fotografie, textové pasáže -, niektoré pravdepodobne využíva ako potvrdzujúce doloženie „reálnosti“ fikčných alebo fikčne pozmenených objektov (fotografie $\mathrm{z}$ rodinných archívov Bánovčanov sú popísané ako fotografie postáv románu). Fikčný text románu Nedelné šachy s Tisom využíva historické stopy inak ako predchádzajúce knihy: neodvodzuje z nich priamočiaro svoju výstavbu a významové vrstvy ani neoddeluje mimotextové reálie od ich príbehového spracovania, ale vpúšta stopy priamo do textu, homogenizuje ich s fikčným okolím, aby prostredníctvom novostvoreného sveta vypovedali - v možno pozmenených súvislostiach, možno naliehavejšie alebo účinnejšie - o tom, čo zastupujú z minulého historického diania. ${ }^{11}$

Podobný postup uplatnil Lavrík aj v knihe Posledná barónka. Kniha je bohato vybavená materiálmi autenticky súvisiacimi so životom protagonistky románu Margity Czóbelovej: použité reprodukcie jej obrazov a fotografie pochádzajú z fondov a archívov Slovenskej národnej galérie. Na predsádkach je Margitina domáca úloha $\mathrm{z}$ nemčiny a fotografie i písomnosti z rodinného archívu. Na prvej strane sa nachádza ilustrácia s názvom „Biele pávy“, na štvrtej strane je jeden z početných autoportrétov Margity Czóbelovej atd’. Rozsiahly súbor stôp umožňuje výpravný grafický plán publikácie, no hlavne reprezentuje konkrétnu osobu stojacu v centre témy. Autor dbal o čo najspolahlivejšie sprostredkovanie výrazného životného príbehu barónky Czóbelovej. V podakovaní explicitne formuluje svoj zámer, zvolený postup a pomer medzi historickou vernostou a fikciou:

Chcem sa na tomto mieste aj ospravedlnit za každú nedôslednost', nepresnost či neúplnú informáciu. Ak sa tak pri tvorbe tohto príbehu stalo, môžu za to len a len osobnostné limity pisatela a vydavatelova dohoda s tlačiarňou, že kniha nebude mat viac než poltisícku strán. Pokial ide o mieru fabulácie, ktorej som sa dopustil, na svoju česț vyhlasujem, že mojím zámerom nebolo tromfnút historické reálie. Uchýlil som sa k nej len tam, kde bolo treba rozkryt zájdené či nepovšimnuté súvislosti, historický kontext alebo nájst prínosný zorný uhol či spôsob rozprávania, ktorý paradoxy doby pomôže čitatelovi strávit. A na záver ešte prosba, vážený čitatel. Nech mi je odpustené, že hranica medzi literatúrou faktu a fikciou ostane v tomto dokumentárnom románe rozostrená (Lavrík 2019).

Žáner dokumentárneho románu napriek silnej väzbe na historickú rekonštrukciu minulého neprotirečí charakteristike fikčného textu, čo potvrdzujú aj Lavríkove autorské metódy. Korpus autentických materiálov nadobúda románový život prostredníctvom fikčnej línie zastúpenej rozprávačom a jeho životným príbehom (kompletný názov románu je Posledná barónka. Zipser Landbuch Šlauka Probiera. Dokuromán). Iným príkladom prelínania dokumentárneho a fiktívneho je rozsiahla korešpondencia medzi Margitou Czóbelovou a jej životnou láskou. Pravdepodobne menšia čast z nej je autentická, dalšiu čast’ vytvoril autor. Hra s čitatelom je tým skomplikovaná: súbor písomností, obrazov, fotografí je „pravý", nezamenitelným spôsobom vypovedá o protagonistke rozprávania, no vnútri dokurománu je zároveň kontaminovaný vymyslenými súčastami. Ako celok má teda mierne ambivalentnú povahu; autentické doklady sú platné rovnako ako v aktuálnom svete, ale na nerozoznanie od nich sú v texte prítomné i „podvrhy“. Žáner historického románu im umožňuje spolunažívat v záujme naplňania autorovho zámeru. 


\section{ZÁVER}

Na základe uvedených príkladov možno formulovat niekolko záverečných konštatovaní o zvláštnostiach literárnej transformácie $\mathrm{v}$ žánroch historickej prózy. Pri teoretickom opise - napríklad v rámci teórie fikčných svetov - platia pre historické romány všetky charakteristiky fikčnej literatúry. To znamená, že tematické zložky prevzaté z minulého diania $\mathrm{v}$ aktuálnom svete prechádzajú po vstupe do textu ontologickou premenou: zo stôp historika sa stávajú pre autora prvkami fikčného textu, homogénnymi so súčastami stvorenými len samotným textom. Pôvodná stopa však ani prechodom do fikčného textu neprerušuje súvislost' so svojou mimotextovou verifikačnou silou. Práve na jej pozadí môže autor uplatnit a čitatel' rozpoznávat̉ rozmanité modifikácie fikčného náprotivku stopy v texte. Takto pretvorená súčast textu je podriadená tvarovaniu témy na jednotlivých úrovniach naratívnych transformácií až po úroveň diskurzu ako verbálnej prezentácie rozprávania. ${ }^{12} \mathrm{~K}$ naznačenému teoretickému ponímaniu možno pridat pragmatický aspekt literárnej komunikácie: fikčné texty vznikajú a fungujú na báze pravidiel, ktoré v našej kultúre ustalujú, čo je umelecká literatúra, ako ju čítat a čo možno od nej očakávat. V historickej próze je súčastou pravidiel rozpoznávanie súvztažnosti medzi príslušnými tematickými prvkami a historickým poznaním a zároveň sledovanie tvorivého transferu, ktorému sa tieto prvky podrobujú, aby spoluvytvorili nové horizonty významu prístupné v rámci hry platnej pre recepciu fikčnej literatúry.

\section{POZNÁMKY}

1 „[P]roces, jenž transformuje archivní zdroje do podoby narativní historie [sa] kvalitativně liší od procesu, který transformuje romanopiscovy zdroje [...] do podoby jeho fikčního výtvoru. [...] První z těchto procesů je výrazně omezen a regulován, vyžaduje zdůvodnění ze strany autora a podléhá čtenářské kontrole“ (Cohnová 2009, 144 - 145).

2 Variabilnost začleňovania historických stôp do fikcie dobre preukazuje napr. Judit Görözdi v knihe zameranej na súčasné madarské romány (2019).

3 V inej súvislosti poukázal na pootváranie sa referencie fikčného textu k súčastiam aktuálneho sveta Petr A. Bílek na príklade vlastných mien postáv, ktoré majú korelát $\mathrm{v}$ historických osobnostiach: „Fikční svět [...] je zakládán a zabydlován různorodými způsoby na celé škále od těch zcela intenzionálních (odkazujících vesměs dovnitř textu) až po zcela extenzionální, které pootevírají prostor referenci $\mathrm{k}$ aktuálnímu světu [...]. Vlastní jména jsou jen jedním z viditelných dokladů; obdobně ale fungují i reference vůči stěžejním událostem a stavům jevů a věcí. I v těchto případech získává daný fikční svět odkazem k entitě aktuálního světa rychle, produktivně a relativně trvale bohatou významovou náplň, kterou by za předpokladu pouze vnitřnětextové tvorby významu a smyslu musel suplovat rozsáhlými textovými pasážemi“ $(2011,114)$.

4 „Na švu mezi textem a ,textem života se nápadněji než mnohde jinde v textu odehrává zápas o tvar a smysl díla, k němuž neodmyslitelně patří zaujetí postoje ke vztahu textu a mimotextové skutečnosti [zvýr. I. J.] a k němuž dochází výrazněji než jinde právě v rámcových partiích textu, zejména na jeho začátku“ (Hodrová 2001, 223).

5 Zastavte Dubčeka! Príbeh človeka, ktorý prekážal mocným (Banáš 2009); Pentcho. Príbeh parníka. Rozširená verzia filmového scenára NA DRUGU STRONU (Rihák 2015).

6 Recenzent v tejto súvislosti hodnotí: „To, čo [Banáš] napísal, nestojí za vela. Kapitolu po kapitole čitatel' zistuje dôležitú vec, a to tú, že Banášova kniha postupuje presne podla Dubčekových pamätí Nádej zomiera posledná, Mlynářovej knihy Mráz přichází z Kremlu a Sukovho diela Labyrintem 
revoluce. Nie však doslova, Banáš ich beletrizuje, dialogizuje (niekedy sú to však len tažko uveritelné či naivné dialógy, ako napríklad Dubčekov rozhovor s manželkou o nedostatku vajec), ale takmer nič nové (okrem niekolkých kapitol venovaných politickej situácii) nepridáva. Ak sa chce niečo človek dozvediet’ o Dubčekovom živote, je ovela rozumnejšie siahnut po jeho pamätiach, Mlynářovi a Sukovi“ (Gális 2010).

7 „Napísané podla rozhovorov s Alexandrom Citronom, Feri Neumannom, Josefom Herczom a Štefanom Strelingerom. Príbeh parníka Pentcho je skutočný, naozaj sa stal. Mená postáv sú zmenené, mená historických postáv uvádzam v pôvodnej podobe. Toto nie je práca historika, aj ked’ hovorí o histórii. Je to filmový scenár. V scenári aj v románe sa niekedy dejú veci inak. Sadnite si a pustite si film“" (Rihák 2015, 5).

8 „,Ved' historický román - to je román o tom, čo autor nikdy nevidel. Autor, zatažený odstupom a zrelostou svojho storočia, môže sa uistovat', kolko chce, že dobre pochopil, ale vžit sa aj tak nemôže, a teda, je historický román predovšetkým román fantastický?` Alexander Solženicyn: Súostrovie Gulag II (6. kap.)“ (Rankov 2011, 4).

9 „,V debnách sme nazhromaždili všelijaké spisy a svedectvá. Hrôzostrašné veci, štatistiky, plány táborov a väzení, listy internovaných ludí, tajné rozhodnutia a, prirodzene, výstrižky z novín. Všetky tie dokumenty nám prichodili vel’mi vzrušujúce, ked’ sme ich zozbierali, ale bolo čudné, že zakrátko nám naša korist pripadala nezaujímavá a všedná. 'Ismail Kadare: Spiritus (Prvá čast' Chaos)“ (Rankov 2011, 4).

10 „Syn môj, zmiluj sa nado mnou, ktorá som ta devät mesiacov v živote nosila, tri roky nadájala, živila som ta a starostlivou opaterou priviedla až do tohto veku. Prosím tá, dieta moje, pozri na nebo a na zem, všimni si všetko, čo je na nich, a poznáš, že Boh ich stvoril z ničoho a že ludské pokolenie takisto povstalo. Neboj sa tohto kata, ale ukáž, že si hoden svojich bratov! Podstúp smrt', aby som ta opät získala aj s tvojimi bratmi v deň onoho zmilovania.' Druhá kniha Machabejcov (2 Mach 7, 27 - 29)“ (Rankov 2011, 4).

${ }^{11}$ O naratívnych postupoch v románe a ich účinkoch, najmä o osobitostiach zvoleného typu rozprávačky podnetne diskutovali Marta Součková, Vladimír Barborík, Radoslav Passia a Peter Zajac v literárnom klube LQ - literárny kvocient 9 (Součková et al. 2017).

${ }^{12}$ Pokial ide o bohatost možných významov a intelektuálne či emocionálne podnety textu, samotná prítomnost tematických prvkov s historickými korelátmi nič nezaručuje. Stručné sondy do vybraných textov dávajú za pravdu konštatovaniu P. A. Bíleka: „V obecné rovině je nejspiš udržitelné tvrdit, že čím je dílo významově bohatší ( $t j$. potřeba nalézat dostatek významového dění se saturuje už vnitřním uspořádáním textu), tím méně se pootevírá nutnosti ,parazitovat' na konkrétních stavech jevů a věcí ve světě aktuálním. Naopak dílo významově nevydatné [...] se pak stává mnohem senzitivnějším vůči těmto vlivům aktuálního světa. Estetická funkce v něm nedokáže eliminovat funkce ostatní a dílo se pootevírá čtení, v němž stěžejní roli hraje funkce reprezentační (resp. expresivní či apelativní)“(2011, 115).

\section{PRAMENE}

Banáś, Jozef. 2009. Zastavte Dubčeka! Príbeh človeka, ktorý prekážal mocným. Bratislava: Ikar.

Lavrík, Silvester. 2016. Nedelné šachy s Tisom: Historický román inšpirovaný historickými udalostami a príbehmi ludí, ktorí ich museli žit'. Bratislava: Dixit.

Lavrík, Silvester. 2019. Posledná barónka: Zipser Landbuch Šlauka Probiera. Dokuromán. Bratislava: Dixit - Iron Libri.

Rankov, Pavol. 2011. Matky. Pusté Úlany: Edition Ryba.

Rihák, Jaro. 2015. Pentcho: Príbeh parníka. Rozšírená verzia filmového scenára NA DRUGU STRONU. Bratislava: Marenčin PT. 


\section{LITERATÚRA}

Bílek, Petr. A. 2011. „Možnosti naratologie v rámci kulturálních studií.“ In Cosmogonia: Alegorické reprezentace „všeho“, Petr A. Bílek, 112 - 121. Praha: Akropolis.

Bílik, René. 2008. Historický žáner v slovenskej próze. Bratislava: Kalligram - Ústav slovenskej literatúry SAV.

Cohnová, Dorrit. 2009. Co dělá fikci fikcí. Prel. Milan Orálek - Veronika Klusáková. Praha: Academia.

Doležel, Lubomír. 2002. „Fikční a historický narativ: setkání s postmoderní výzvou.“ Česká literatura 50, 4: $341-370$.

Gális, Tomáš. 2010. „Nepodarený pomník Alexandra Dubčeka.“ Sme, 19. február. Dostupné na: https:// kultura.sme.sk/c/5250433/nepodareny-pomnik-alexandra-dubceka.html [cit. 9. 2. 2021].

Görözdi, Judit. 2019. Dejiny v súčasných madarských románoch. Bratislava: Veda, vydavatel’stvo SAV - Ústav svetovej literatúry SAV.

Hodrová, Daniela a kol. 2001. ...na okraji chaosu...: Poetika literárního díla 20. století. Praha: Torst.

Kubíček, Tomáš. 2010. „Př́spěvek k návrhu definice historického žánru.“ Slovenská literatúra 57, 1: $85-95$.

Pavel, Thomas G. 2012. Fikční světy. Prel. Zikmund Hynek. Praha: Academia.

Součková, Marta et al. 2017. „LQ - literárny kvocient 9: Konvália/Nedelné šachy s Tisom.“ Dostupné na: https://www.youtube.com/watch?v=9hX1lsXfmrw [cit. 19. 9. 2021].

Višňovský, Emil. 2019. Veda ako sociokultúrna praktika. Bratislava: Univerzita Komenského v Bratislave.

\section{Between historical fact and fiction: interdiscursivity of fictional worlds in contemporary Slovak prose with historical themes}

Interdiscourse. Historical trace. Fictional text. Historical genre.

This article pays attention to the relation between historical knowledge and historical prose. It describes the historical genre as an interdiscursive invariant of author and reader conventions. Its production and reception variants activate interdiscursive action, important for the proper functioning of the genre convention. The author focuses on thematic elements, which in historical knowledge represent a trace of the past - a proof of past events. The writer incorporates documents, photographs, facts found in archives, findings of archaeologists, etc. into the theme of the text. In examining different ways of incorporating these traces existing behind the text into fiction, the article treats Jozef Banášs Zastavte Dubčeka! (Stop Dubček!, 2009), Jaro Rihák's Pentcho (2015), Pavol Rankov's Matky (Mothers, 2011) and Silvester Lavrík’s Nedelné šachy s Tisom (Sunday chess with Tiso, 2016) and Posledná barónka (The last Baroness, 2019). In historical prose, the rules of text reception include recognizing the correlation between the thematic elements and historical knowledge, as well as observing the creative transfer these elements undergo to co-create new horizons of meaning.

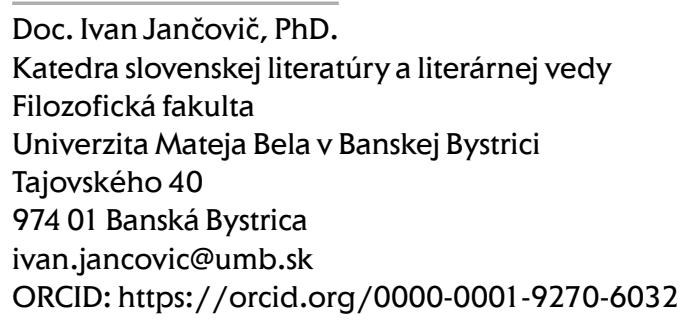

